\title{
PENERAPAN MODEL PEMBELAJARAN THINK TALK WRITE DALAM PEMBELAJARAN MENCERITAKAN KEMBALI ISI TEKS BIOGRAFI DENGAN MEDIA CETAK
}

\author{
Pipit Dewi Puspitasari, Sarwiji Suwandi, Raheni Suhita \\ Universitas Sebelas Maret \\ Surel: dewi.pipit26@gmail.com
}

\begin{abstract}
This study aims to describe the quality of the learning process and the skills of retelling the contents of the biographical text with the print media using the Think Talk Write model of learning in students of class X Motorcycle Technique (TSM) B SMK Gamaliel 1 Madiun. This study is a Classroom Action Research (PTK) which is implemented in two cycles, with each cycle consisting of four stages, namely planning, action, observation, and reflection. Subjects in this study were students of class X TSM B consisting of 21 male students. Data collection techniques used in this study include observation, field notes, interviews, documentation, and ability tests. This research used compative descriptive data anlysis technique. The results showed that the application of Think Talk Writelearning model with print media can improve the quality of the learning process and the skills of retelling the content of the biography of the students in cycle I and cycle II. This is indicated by the improvement of process quality from cycle I with an average score of 71,42 increased in cycle II with an average score of 90,47. Then, skill enhancement retells the contents of the biography text in cycle I with an average score of 70,42 increases in cycle II with an average score of 82,80.
\end{abstract}

Keywords: biographical texts, media, think talk write models.

\begin{abstract}
Abstrak:Penelitian ini bertujuan untuk mendeskripsikan kualitas proses pembelajaran dan keterampilan menceritakan kembali isi teks biografi dengan media cetak mengunakan model pembelajaran Think Talk Write pada siswa kelas X Teknik Sepeda Motor (TSM) B SMK Gamaliel 1 Madiun. Penelitian ini merupakan Penelitian Tindakan Kelas (PTK) yang dilaksanakan dalam dua siklus. Subjek dalam penelitian ini adalah siswa kelas X TSM B yang terdiri dari 21 siswa laki- laki. Penelitian ini menggunakan teknik analisis data deskriptif komparatif. Hasil penelitian menunjukkan bahwa penerapan model pembelajaran Think Talk Write dengan media cetak dapat meningkatkan kualitas proses pembelajaran dan keterampilan menceritakan kembali isi teks biografi siswa pada siklus I dan siklus II. Hal ini ditunjukkan dengan adanya peningkatan kualitas proses dari siklus I dengan skor rata- rata 71,42 meningkat pada siklus II dengan skor rata- rata 90,47. Kemudian, peningkatan keterampilan menceritakan kembali isi teks biografi pada siklus I dengan skor rata- rata 70,42 meningkat pada siklus II dengan skor rata- rata 82,80.
\end{abstract}

Kata Kunci: teks biografi, media cetak, model pembelajaran think talk write.

\section{PENDAHULUAN}

Bahasa memiliki peranan yang sangat penting dalam menunjang tercapainya keberhasilan suatu tujuan pembelajaran. Salah satunya yaitu pembelajaran bahasa Indonesia. Di dalam pembelajaran bahasa Indonesia terdapat empat komponen 
keterampilan berbahasa, meliputi keterampilan menyimak, keterampilan membaca, keterampilan berbicara, dan keterampilan menulis.

Sehubungan dengan hal tersebut, khususnya dalam keterampilan menulis di SMK tentu sudah diajarkan oleh guru, seperti menulis teks laporan hasil observasi, menulis tes anekdot, menulis cerpen, dan lain sebagainya. Namun, pada kenyataan yang ada pada kelas $\mathrm{X}$ berbeda dengan tujuan tersebut. Hampir seluruh siswa belum mampu mengembangkan idenya dalam materi menceritaan kembali isi teks biografi dengan bahasa yang berbeda. Siswa masih mengalami kesulitan atau kendala dalam mengembangkanidenya dikarenakan guru belum sepenuhnya membimbing secara intensif serta mengembangkan model pembelajaran yang tepat dalam proses pembelajaran di kelas. Pembelajaran menceritakan kembali isi teks biografi yang ideal yaitu dengan menerapkan langkah-langkah menceritakan kembali isi teks biografi.

Berdasarkan informasi yang diperoleh peneliti dari hasil wawancara dengan guru bahasa Indonesia SMK Gamaliel 1 Madiun, diketahui bahwa penyebab rendahnya keterampilan menceritakan kembali isi teks biografi ialah siswa kurang memperhatikan penjelasan guru, siswa belum memiliki keberanian mengutarakan pendapat, siswa kurang antusias dalam mengikuti pembelajaran, kurangnya minat membaca dan menulis, serta siswa belum berani mempresentasikan hasil pekerjaannya.

Berdasarkan permasalahan yang ada di lapangan, perlu adanyatindakan yaitu dengan menerapkan suatu pembelajaran inovatif. Model pembelajaran yang sesuai yaitu Think Talk Write dengan media cetak. Model pembelajaran ini merupakan strategi guru dalam menggunakan alat bantu atau media gambar untuk menerangkan sebuah materi atau memfasilitasi siswa untuk aktif belajar. Kelebihan dari model pembelajaran ini adalah dapat mengembangkan keterampilan berpikir kritis dan kreatif siswa.

Sebelum memahami lebih jauh mengenai teks biografi, perlu diketahui dahulu pengertian teks. Menurut Mahsun (2014: 1), teks didefinisikan sebagai 
satuan bahasa yang digunakan sebagai ungkapan suatu kegiatan sosial baik secara lisan maupun tulis dengan struktur berpikir yang lengkap.

Biografi berasal dari bahasa Yunani, yakni dari kata 'bios' yang artinya hidup dan 'graphein' yang berarti tulis. Menurut Fuad (2012: 24), teks biografi merupakan riwayat hidup seseorang yang ditulis oleh orang lain. Penulis sebagai pemilik hak atas kekayaan intelektual atas penulisannya bertanggung jawab atas risiko hukum buku tersebut, sementara tokohyang ditulis hanya sebagai narasumber. Pendekatannya penulis sebagai orang ketiga.

Wahono, Mafrukhi, dan Sawali (2013: 197) mengungkapkan teks biografi adalah teks yang bersifat faktual yang artinya apa yang disampaikan berdasar fakta- fakta. Fakta tersebut berupa identitas tokoh, keistimewaan, perjuangan, kesuksesan, rintangan, dan pelajaran hidup tokoh. Teks biografi memuat banyak hal tentang kehidupan tokoh. Hal yang paling menonjol dalam teks biografi adalah keistimewaan tokoh.

Dalam jurnal yang ditulis oleh Dwi Cahyadiantari, dkk. (2017) dijelaskan bahwa teks biografi merupakan teks yang di dalamnya berisi fakta- fakta kehidupan seseorang yang bersifat penting. Teks biografi menceritakan kehidupan seorang tokoh penting atau terkenal maupun tidak terkenal. Dalam Kemendikbud(2014: 37), diuraikan bahwa teks biografi merupakan teks yang menceritakan riwayat hidup seseorang yang ditulis oleh orang lain berdasarkan fakta peristiwa yang dialami tokoh semasa hidupnya.Dalam teks biografi, tokoh diceritakan dari lahir hingga bisa meraih cita- cita yang diinginan dengan mengalami berbagai peristiwa dan masalah.

Beberapa pengertian teks biografi di atas, peneliti menyimpulkan bahwa teks biografi ialah teks berisi tentang perjalanan hidup dan prestasi seorang tokoh yang telah di tulis olehorang lain. Perjalan hidup dari tokoh yang dibiografikan tersebut ditulis berdasaran fakta- fakta kehidupan tokoh yang sifatnya penting.Teks biografi lebih menonjolkan keistimewaan dari seseorang. Sebagai contoh dari keistimewaan tersebut ialah prestasi dari tokoh, cita- cita yang diinginkan, kesuksesan, dan lain sebagainya yang memiliki nilai jual. 
Dalam pembahasan ini lebih menekankan pada menceritakan kembali isi teks biografi dengan bahasa yang berbeda. Oleh karena itu, siswa dituntut untuk mampu menemukan ide pokok atau gagasan pokok dari setiap paragraf, kemudian dihubungkan menjadi paragraf yang utuh dengan menggunakan konjungsi yang tepat dan penggunaan bahasa yang baik dan benar. Menceritakan kembali isi teks biografi yang dimaksudkan, seperti halnya membuat ringkasan cerita.

Daryanto (2011: 54) menyebutkan bahwa kualitas pembelajaran adalah tingkat pencapaian tujuan pembelajaran, termasuk dalam pembelajaran seni. Pencapaian tujuan tersebut berupa peningkatan pengetahuan dan keterampilan serta pengembangan sikap melalui proses pembelajaran. Selain itu, Hamdani (2010: 193) menyatakan kualitas dapat dimaknai dengan istilah mutu atau keefektifan. Secara difinitif, efektivitas dapat dinyatakan sebagai tingkat keberhasilan dalam mencapai tujuan atau sasarannya (Etzioni dalam Hamdani, 2010: 194).

Dalam jurnal D.A. Wagner (2010) dijelaskan tentang educational quaality, the subject of the 2005 EFA Global Monitoring Report(UNESCO, 2004), has several core components, including: (1) what learners should; (2) where learning occurs; (3) how learning takes; and4) what is actually learned.Berdasarkan uraian diatas, dapat disimpulkan bahwa kualitas belajar dapat dimaknai dengan tingkat pencapaian tujuan pembelajaran. Pencapaian tujuan tersebut berupa peningkatan pengetahuan dan keterampilan serta pengembangan sikap melalui proses pembelajaran.

Selanjutnya, masalah penelitian dapat dirumuskan sebagai berikut. Pertama, Bagaimanakah penerapan model pembelajaran Think Talk Write dalam meningkatkan kualitasproses pembelajaran kemampuan menceritakan kembali isi teks biografi dengan media cetak siswa kelas X TSM B SMK Gamaliel 1 Madiun?. Kedua, Bagaimanakah penerapan model pembelajaran Think Talk Write dalam meningkatkan kemampuan menceritakan kembali isi teks biografi dengan media cetak siswa kelas X TSM B SMK Gamaliel 1 Madiun?. Adapun tujuan penelitian ini adalah meningkatkan: (1) kualitas proses pembelajaran 
menceritakan kembali isi teks biografi, (2) kemampuan menceritakan kembali isi teks biografi siswa kelas X Teknik Sepeda Motor (TSM) B SMK Gamaliel 1 Madiun.

Melihat permasalahan yang terjadi, peneliti merasa tertarik untuk mengatasi masalah tersebut. Peneliti menerapkan model pembelajaran Think Talk Write (TTW) untuk meningkatkan kualitas proses pembelajaran dan kemampuan menceritakan kembali isi teks biografi dengan media cetak siswa kelas X Teknik Sepeda Motor (TSM) B SMK Gamaliel 1 Madiun.

Menurut Huda (2013: 218) strategi Think Talk Write (TTW)mendorong siswa untuk berpikir, berbicara, dan kemudian menuliskan suatu topik tertentu. Dalam strategi Think Talk Write terdapat tiga fase dalam kegiatannya, yaitu Think (proses membaca suatu teks yang kemudian setelah membaca teks tersebut dilanjutkan dengan membuat catatan apa yang telah dibaca), Talk (berkomunikasi menggunakan kata- kata dan bahasa yang mereka pahami), dan Write (menuliskan hasil diskusi/ dialog pada lembar kerja yang disediakan).

Menurut Daryanto (2010: 157) media adalah segala sesuatu yang dapat digunakan untuk menyalurkan pesan dari pengirim ke penerima sehingga dapat merangsang pikiran, perasaan, perhatian, dan minat serta perhatian siswa sedemikian rupa sehingga proses belajar mengajar terjadi. Sedangkan Zainal (2014: 50) menyatakan pengertian dari media pembelajaran ialah sebagai berikut,

(a) perantara, pengantar, (b) media pembelajaran: segala sesuatu yang dapat digunakan untuk menyalurkan pesan dan merangsang terjadinya proses belajar pada si pembelajara (siswa), (c) makna media pembelajaran lebih luasdari: alat peraga, alat bantu mengajar, media audio visual, (d) guru hanya merupakan salah satu jenis sumber belajar yang berupa "orang".

Dalam pembelajaran bahasa Indonesia khususnya materi menceritakan kembali isi teks biografi, media yang sesuai yaitu media cetak. Media cetak yang digunakan berupa media biografi. Menurut Indriana (2011: 63) media biografi memiliki kelebihan dapat menyajikan pesan atau informasi dalam jumlah banyak, pesan dapat dipelajari siswa sesuai dengan kebutuhan, minat, dan kecepatan 
masing- masing, dapat dipelajari kapan saja karena bisa dibawa kemanapun. Kadang tampilan lebih menarik ketika dilengkapi dengan gambar dan warna.

Oleh karena itu, dalam pembelajaran keterampilan menceritakan kembali isi teks biografi, media biografi dapat digunakan dalam pembelajaran karena media biografi ini merupakan media yang lebih efektif dan mampu memotivasi siswa dalam mengeluarkan ide- ide yang ada dipikiran setiap siswa mengenai biografi tooh yang telah diberikan. Bahkan, dengan media biografi dapat membantu siswa untuk memahami karakter seorang tokoh dan hal- hal penting yang terjadi dalam kehidupan tokoh tersebut.

\section{METODE PENELITIAN}

Penelitian ini menggunakan Penelitian Tindakan Kelas (PTK). Dalam Kunandar(2009 : 44- 45) menyatakan bahwa penelitian tindakan kelas dapat didefinisikan sebagai suatu penelitian (action research) yang dilakukan oleh guru yang sekaligus sebagai peneliti di kelasnya atau bersama- sama dengan oranglain (kolaborasi) dengan jalan merancang, melaksanakan dan mere- fleksikan tindakan secara kolaboratif dan partisipatif yang bertujuan untuk memperbaiki atau meningkatkan mutu (kualitas) proses pembelajaran di kelasnya melalui suatu tindakan (treatment) tertentu dalam suatu siklus.

Subjek penelitian adalah siswa yang menjadi sasaran pelaksanaan tindakan. Siswa yang menjadi subjek penelitian ialah siswa kelas X Teknik Sepeda Motor (TSM) B SMK Gamaliel I Madiun. Dari jumlah siswanya di kelas berjumlah 21 siswa laki- laki.

Teknik analisis data yang digunakan dalam penelitian tindakan kelas ini adalah teknik analisis deskriptif komparatif. Indikator yang ingin dicapai yaitu kualitas proses dan kualitas hasil keterampilan menceritakan kembali isi teks biografi dengan media cetak menggunakan model pembelajaran Think Talk Write dapat meningkat. Indikator kinerja dalam penelitian ini ditentukan berdasarkan hasil diskusi guru dengan peneliti. Keberhasilan produk dapat dilihat dari peningkatan nilai menceritaan kembali isi teks biografi di setiap akhir siklus. 
Apabila $75 \%$ siswa di kelas mendapatkan nilai lebih besar dari KKM atau sama besar dengan nilai KKM mata pelajaran Bahasa Indonesia, yaitu sebesar 72.

Prosedur penelitian yang digunakan ialah berbentuk siklus. Siklus ini tidak hanya berlangsung satu kali, tetapi dapat beberapa kali sampai tujuan yang diharapkan dalam pembelajaran tercapai. Arikunto, dkk (2011: 16) mengemukakan bahwa secara garis besar terdapat empat tahapan yang lazim dilalui dalam PTK yaitu (1) perencanaan, (2) pelaksanaan, (3) pengamatan, dan (4) refleksi. Penelitian tindakan kelas yang dilakukan terdiri atas dua siklus, tiap siklusnya terdiri dari dua kali pertemuan.

\section{HASIL PENELITIAN DAN PEMBAHASAN}

Penelitian ini dilaksanakan dalam 2 siklus. Tiap siklusnya dilakukan selama dua kali pertemuan. Sesuai dengan langkah- langkah penelitian tindakan kelas, yaitu (1) perencanaan, (2) tindakan, (3) pengamatan, dan(4) refleksi.

Tahap perencanaan dalam penelitian ini peneliti menyepakati penerapan model pembelajaran Think Talk Write (TTW) dengan media cetak dalam pembelajaran keterampilan menceritakan kembali isi teks biografi dalam menyusun RPP, menyiapkan lembar observasi, dan menyiapkan instrumen penilaian.

Pada siklus I pertemuan pertama, guru mulai mongkondisikan siswa untuk berkonsentrasi dalam pembelajaran dengan mengenalkan model pembelajaran Think Talk Write. Guru memberikan materi tentang menceritakan kembali isi teks biografi. Kemudian, guru membagikan teks biografi. Selanjutnya, guru meminta siswa untuk membuat kelompok. Tiap kelompok terdiri dari 3- 4 siswa. Setelah itu, siswa diminta untuk membaca teks biografi yang telah dibagikan guru dan memikirkan ide pokok dari masing- masing paragraf. Kemudian, didiskusikan bersama dengan anggota kelompoknya masing- masing untuk menghubungkan ide pokok dari masing- masing paragraf menggunakan bahasa yang baik dan benar dalam bentuk cerita ulang di lembar jawaban. 
Pada siklus I pertemuan kedua guru mengawali pembelajaran sesuai dengan RPP, seperti melakukan apersepsi dan memotivasi siswa. Kemudian menyampaikan tujuan pembelajaran yang akan dicapai dengan melanjutkan pembelajaran pada pertemuan yang sebelumnya. Guru meminta siswa untuk menyelesaikan tugasnya, yaitu menceritakan kembali isi teks biografi. Setelah tugas tersebut selesai guru meminta siswa untuk mempresentasikan hasil diskusinya ke depan kelas. Guru juga memberikan penilaian terhadap hasil pekerjaan siswa. Kemudian, guru menyampaikan refleksi mengenai pembelajaran siklus I dengan memberikan motivasi dan saran kepada siswa agar terus mengembangkan keterampilan menceritakan kembali isi teks biografi dengan lebih baik lagi dalam pertemuan berikutnya. Setelah itu, guru mengakhiri pembelajaran dengan salam. Begitu pula dengan pertemuan pada siklus II langkah- langkah pembelajaran sama dengan siklus I.

Berdasarkan hasil pengamatan dan analisis data pada siklus I dan siklus II dapat disimpulkan bahwa penerapan model pembelajaran Think Talk Write (TTW) dapat meningkatkan kualitas proses dan keterampilan menceritakan kembali isi teks biografi dengan media cetak. Peningkatan tersebut dapat diketahui dari kinerja guru, kinerja siswa, dan hasil kemampuan siswa dalam menceritakan kembali isi teks biografi. Berikut penjabaran pembelajaran keterampilan menceritakan kembali isi teks biografi.

\section{Peningkatan Kualitas Proses Pembelajaran Menceritakan Kembali Isi Teks Biografi}

Berdasarkan hasil observasi antara siklus I dan siklus II dalam pembelajaran menceritakan kembali isi teks biografi dengan media cetak menggunakan model pembelajaran Think Talk Write dapat diketahui bahwa telah terjadi perubahan tingkat kualitas proses pembelajaran siswa. Siswa memperoleh skor sesuai dengan aspek yang diamati dalam proses pembelajaran. 


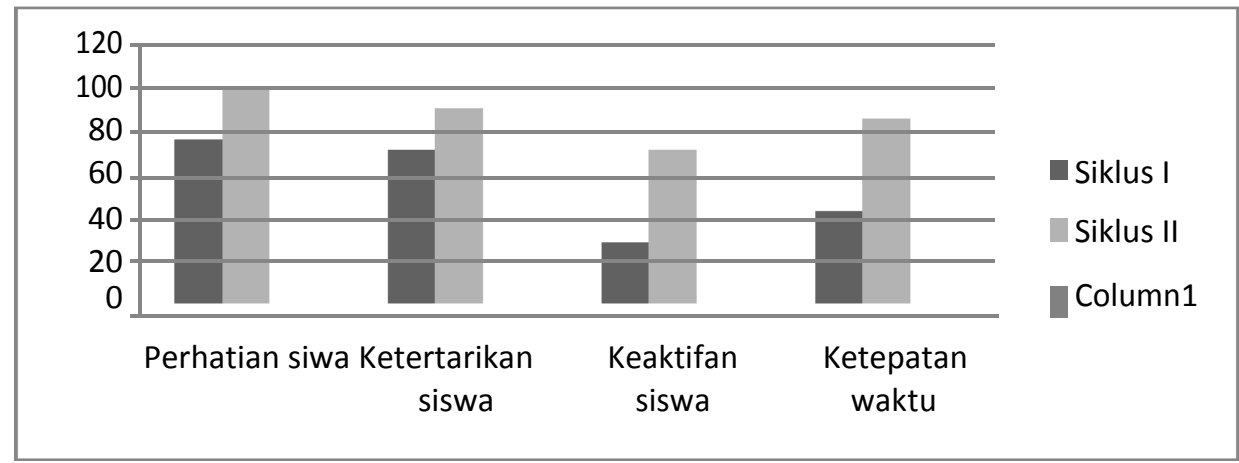

Gambar 1. Diagram Rekapitulasi Kualitas Proses Pembelajaran Menceritakan Kembali Isi Teks Biografi pada Sikus I dan Siklus II

Berdasarkan hasil kualitas proses pembelajaran di atas, dapat diketahui bahwa terjadi peningkatan dari siklus I ke siklus II. Pada siklus I, aspek perhatian siswa menunjukkan hanya beberapa siswa yang kurang memperhatikan guru dalam proses pembelajaran. Sedangkan padasiklus II, aspek perhatian siswa menunjukkan seluruh siswa memperhatikan guru dalam proses pembelajaran.

Padasiklus II, menunjukkan bahwa siswa tertarik mengikuti proses pembelajaran sejak awal sampai akhir. Kemudian, aspek keaktifan siswapada siklus I menunjukkan siswa cukup aktif dalam bertanya dan menjawab pertanyaan guru. Pada siklus II menunjukkan bahwa siswa aktifsecara mandiridan kelompok. Selanjutnya, aspek ketepatan waktu pada siklus I menunjukkan $50 \%$ siswa mengumpulkan tugas tepat waktu. Sedangkan, pada siklus II menunjukkan bahwa $100 \%$ siswa mengumpulkan tugas tepat waktu. Dengan demikian, dapat disimpulkan bahwa pada siklus I ke siklus IItelah menunjukkan adanya peningkatan kualitas proses pembelajaran menceritakan kembali isi teks biografi.

\section{Peningkatan Kemampuan Menceritakan Kembali Isi Teks Biografi}

Penelitian ini menunjukkan bahwa keterampilan menceritakan kembali isi teks biografi ini didasarkan pada hasil penelitian tindakan siklus I dansiklus II. Hasil penelitian ini pada tiap siklusnya diperoleh melalui data tes keterampilan menceritakan kembali isi teks biografi setelah dilakukannya pembelajaran 
menceritakan kembali isi teks biografi dengan media cetak menggunakan model pembelajaran Think Talk Write pada siswa kelas X TSM B SMK Gamaliel 1 Madiun.

Hasil nilai rata- rata tes padasiklus I, yaitu 70,42. Nilai rata- rata skor tersebut belum mencapai KKM atau masih dalam kategori kurang. Pada siklus I siswa yang mendapatnilai tuntas sebanyak 6 siswa dan 15 siswa mendapat nilai belum tuntas. Nilai terendah pada siklus I, yaitu 66dan nilai tertinggi pada siklus I, yaitu 81. Sehubungan dengan nilai rata- rata pada siklus I belum mencapai KKM, maka peneliti melakukan tindakan pada siklus II. Nilai rata- rata tes pada siklus II, yaitu 82,80 . Hasil tes tersebut menunjukkan telah terjadi peningkatan dari hasil siklus I. Pada siklus II, siswa yang mendapat nilai tuntas, yaitu 19 siswa dan siswa yang mendapat nilai belum tuntas, yaitu 2 siswa. Nilai terendah pada siklus II, yaitu 72 dan nilai tertinggi pada siklus II, yaitu 90 .

Tabel 2. Peningkatan Hasil Keterampilan Menceritakan Kembali Isi Teks Biografi pada Siklus I dan Siklus II

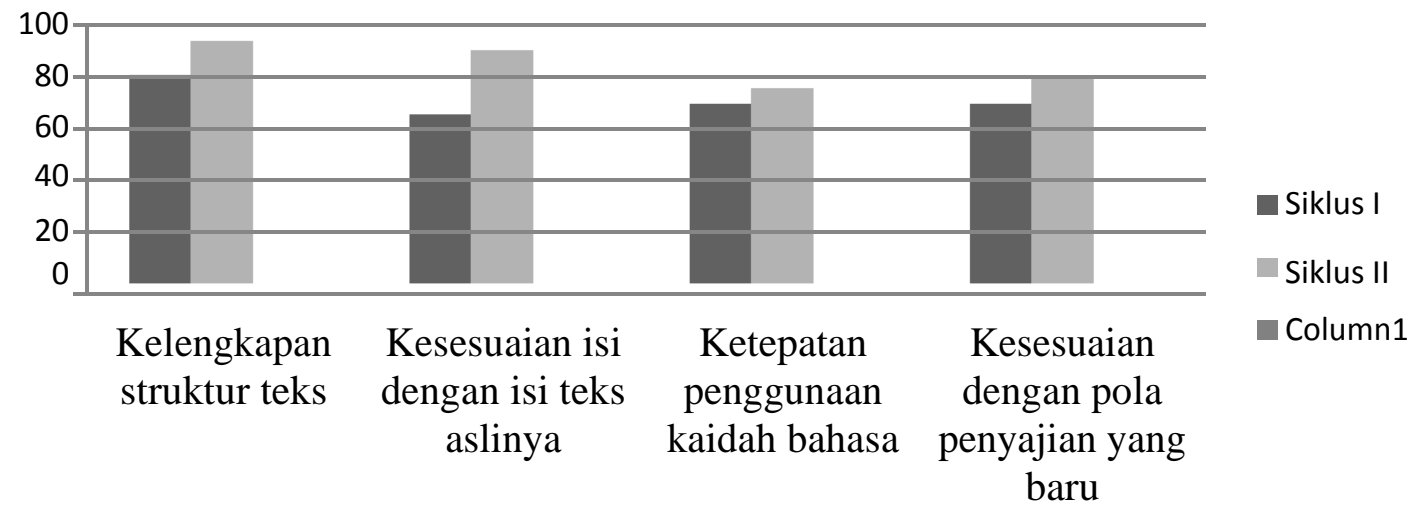

Gambar 2. Diagram Penggunaan Aspek Penilaian

Berdasarkan hasil rekapitulasi data tes keterampilan menceritakan kembali isi teks biografi dari siklus I, dan siklus II dapat dikatakan bahwa keterampilan menceritakan kembali isi teks biografi meningkat. Pada aspek kelengkapan struktur teks, nilai rata- rata siklus II mengalami peningkatan 12,85 dari siklus I. 
Pada aspek kesesuaian isi dengan isi teks aslinya, nilai rata- rata siklus II mengalami peningkatan 24,75 dari siklus I. Pada aspek ketepatan penggunaan kaidah bahasa, nilairata- rata siklus II mengalami peningkatan 6,2 dari siklus I. Pada aspek yang terakhir, yaitu kesesuaian dengan pola penyajian yang baru nilai rata- rata siklus II mengalami peningkatan 10 dari siklus I.

Dengan demikian, dapat disimpulkan bahwa keterampilan siswa per aspek penilaian menceritakan kembali isi teks biografi semakin banyak yang mengalami peningkatan, yaitu sebesar 12,38 dari siklus I. Hal yang membuat pembelajaran meningkat adalah karena siswa bercerita tidak secara individu sehingga mereka lebih percaya diri. Hal demikian juga ditemukan oleh Anindyarini dan Sumarwati. (2014: 66) yaitu dengan bercerita secara kelompok membuat adanya kerja sama dan membuat siswa lebih berani.

\section{SIMPULAN}

Berdasarkan kegiatan penelitian tindakan kelas yang telah dilaksanakan, maka dapat disimpulkan bahwa telah terjadi peningkatan keterampilan menceritakan kembali isi teks biografi dengan media cetak menggunakan model pembelajaran Think Talk Write (TTW) pada siswa kelas X TSM B SMK Gamaliel 1 Madiun. Peningkatan ini terjadi dalam bentuk peningkatan proses dan peningkatan hasil.

Peningkatan proses pembelajaran yang dominan mengalami peningkatan, yaitu aspek perhatian siswa dan ketertarikan siswa terhadap pembelajaran. Pada siklus I aspek perhatian siswa memperleh skor rata- rata 76,19 meningkat menjadi 100 pada siklus II. Kemudian, pada siklus I ketertarikan siswa memperoleh skor rata- rata 71,42 menjadi 90,47 pada siklus II.

Peningkatan nilai siswa dapat dilihat dari skor rata- rata tiap tindakan. Ratarata nilai siswa pada siklus I, yaitu 70,42 dengan kategori kurang, lalu meningkat sebesar 12,38pada siklus II sehingga skor rata- rata siswa pada siklus II sebesar 82,80 dengan kategori sangat baik. 


\section{DAFTAR PUSTAKA}

Anindyarini, A. \& Sumarwati. (2014). Peningkatan Kualitas Pembelajaran Bercerita dengan Metode Kooperatif pada Siswa Sekolah dasar di Kawasan Pedesaan, Jurnal Sekolah Dasar, 23 (1), 60-68.

Aqib, Z. (2014). Model- Model, Media, dan Strategi Pembelajaran Kontekstual (Inovatif). Bandung: Yrama Widya.

Arikunto, S. (2011). Prosedur Penelitian Suatu Pendekatan Praktik. Jakarta: Rineka Cipta.

Arikunto, S. (2013). Prosedur Penelitian Suatu Pendekatan Praktik. Jakarta: Rineka Cipta.

Cahyadiantari, dkk. (2017). Strategi Guru Dalam Pembelajaran Membaca Teks Biografi pada Siswa Kelas VIII SMP Negeri 2 Singaraja. e- Journal Jurusan Pendidikan Bahasa dan Sastra Indonesia, Undiksha. Vol. 7 No. 2

Daniel A. Wagner. (2010). Quality of Education, comparability, and assesment choice in developing counties. Graduate School of Education, University of Pennsylvania, Philadelphia, Pennsylvania, USA. Compare. Vol. 40. No. 6, Desember 2010, 741-760.

Daryanto. (2011). Media Pembelajaran. Bandung: Satu Nusa.

Fuad, Z. (2012). The Secret Of Biography: Rahasia Menulis Biografi Ala Ramadhan K.H. Jakarta: Akademia Permata.

Hamdani. (2010). Strategi Belajar Mengajar. Bandung: Pustaka Setia.

Huda, M. (2013). Model- Model Pengajaran dan Pembelajaran Isu- Isu Metodis dan Pragmatis. Yogyakarta: Pustaka Belajar.

Indriana, D. (2011). Ragam Alat Bantu Media Pengajaran. Yogyakarta: Diva Press.

Kemendikbud. (2015). Buku Siswa Bahasa Indonesia SMA Kelas X. Jakarta: Kementerian Pendidikan dan Kebudayaan Republik Indonesia.

Kunandar. (2009). Guru Profesional. Jakarta: PT Raja Grafindo Persada.

Mahsun. (2014). Teks dalam Pembelajaran Bahasa Indonesia Kurikulum 2013. Jakarta: Rajagrafindo Persada. 
Sardiman. (2011). Interaksi dan Motivasi Belajar Mengajar. Jakarta: Rajawali Pers.

Suminar, R. P. (2015). The Effectiveness of TTW (Think Talk Write) Strategy in Teaching Writing Descriptive Text. Journal pf English Language and Learning. Vol. 2 No.2, Mei 2015. ISSN: 2354-7340.

Wahono, dkk. (2013). Mahir Berbahasa Indonesia. Jakarta: Erlangga 